\title{
Determinants of Occupational Health Problems of Industrial Workers in Coimbatore - Tamil Nadu
}

\section{OPEN ACCESS}

Manuscript ID:

COM-2020-08043450

Volume: 8

Issue: 4

Month: October

Year: 2020

E-ISSN: 2582-6190

Received: 07.08.2020

Accepted: 15.09.2020

Published: 01.10.2020

Citation:

Sangamithra, A., and

P. Sindia. "Determinants of Occupational Health Problems of Industrial Workers in Coimbatore - Tamil Nadu." ComFin Research, vol. 8, no. 4, 2020, pp. 28-31.

DOI:

https://doi.org/10.34293/ commerce.v8i4.3450

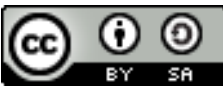

This work is licensed under a Creative Commons Attribution-ShareAlike 4.0 International License

\author{
A. Sangamithra \\ Professor, Department of Economics \\ Bharathiar University, Coimbatore, Tamil Nadu, India \\ https://orcid.org/0000-0003-4761-8150 \\ P. Sindia \\ Research Scholar, Department of Economics \\ Bharathiar University, Coimbatore, Tamil Nadu, India
}

\begin{abstract}
The problems of industrial workers is a matter of concern for the partners of industry, Research scholars, academicians, policy makers, planners, labor leaders, and social workers. Recently there has been a growing awareness of the existence, importance, and needs of the unprotected workers. The unprotected workers are, by definition, disadvantaged workers, the degree varies from section to section. There is a lot of research in the field of unprotected workers. But very few research has been carried out about the unprotected industrial workers belonging to engineering and foundry units, who form a sizeable proportion of the total labor force. There is an immediate need to focus on occupational safety for the formal/organized industrial workers. In India, occupational health safety has so far benefited, only for workers of the formal sector. Against this background, the current study attempted to know the Determinants of Occupational Health Problems of industrial workers in Coimbatore - Tamilnadu. The study found that the sample industrial workers appear to be suffering from occupational-related health problems has increased with an increase in their current age, and such likelihood is also noted as moderately higher among those who are in debt, but unexpectedly such suffering from health problems is also found to be higher among those who own assets.
\end{abstract}

Keywords: Industry, Labor, Environment, Policy, Academics and Economics

\section{Introduction}

Labor plays a vital role in the industrial system for the economic growth of a country. Hence, there is a need for a clear understanding of the different labor problems. The problems of industrial workers is a matter of concern for the partners of industry, Research scholars, academicians, policy makers, planners, labor leaders, and social workers. Recently there has been a growing awareness of the existence, importance, and needs of the unprotected workers. The unprotected workers are, by definition, disadvantaged workers, the degree varies from section to section. There is a lot of research in the field of unprotected workers. But very few research has been carried out about the unprotected industrial workers belonging to engineering and foundry units, who form a sizeable proportion of the total labor force. There is an immediate need to focus on occupational safety for the formal/organized industrial workers. In India, occupational health safety has so far benefited, only for workers of the formal sector. Against this background, the current study attempted to know the Determinants of Occupational Health Problems of industrial workers in Coimbatore - Tamilnadu. 
ComFin Research

\section{Methodology}

The causes of industrial health hazards that pertain to unsafe conditions can include insufficient workspaces such as Lighting, Excessive Noise, Slippery or Unsafe Flooring, Extreme Temperature Exposure, Inadequate Protection When Working with Machinery or Hazardous Materials, Unstable structures, ElectricalProblems, MachineMalfunction, or Failure, and more. The causes of industrial hazards can occur in the environment around the workplace or within the work environment. External causes of industrial hazards may include fires, chemical spills, toxic gas emission, or radiation. The causes of industrial hazards in these cases might include organizational errors, human factors, abnormal operational conditions. The internal causes of industrial accidents can involve equipment or other work-related tangibles, harmful materials, toxic chemicals, and human error (Ezzati $\mathrm{M}$ et al., 2002). It is clear from the above paragraph that workers in the unprotected segment do not enjoy any job security, work security, and social security. The study is confined to Coimbatore is one of the most industrialized cities in Tamil Nadu and is known as the textile capital of South India or the Manchester of South India.

Table 1: Multiple Linear Regression Analysis on No. of Occupational Health Problems

Experienced (12 months preceding survey) by

\begin{tabular}{|l|c|c|c|}
\hline \multicolumn{1}{|c|}{$\begin{array}{c}\text { Explanatory } \\
\text { Variables }\end{array}$} & $\begin{array}{c}\text { Standardized } \\
\text { Regression } \\
\text { Coefficient } \\
(\boldsymbol{\beta})\end{array}$ & $\begin{array}{c}\mathbf{t} \\
\text { value }\end{array}$ & $\begin{array}{c}\mathbf{p} \\
\text { value }\end{array}$ \\
\hline Age (in Years) & 0.192 & 3.771 & 0.001 \\
\hline $\begin{array}{l}\text { Average Individual } \\
\text { Monthly Income (in } \\
\text { Rs.) }\end{array}$ & -0.024 & 0.478 & 0.633 \\
\hline $\begin{array}{l}\text { Education } \\
\text { (8 Categories) }\end{array}$ & -0.154 & 2.274 & 0.01 \\
\hline $\begin{array}{l}\text { Type of Labour } \\
\text { (3 Categories) }\end{array}$ & -0.114 & -1.964 & 0.05 \\
\hline $\begin{array}{l}\text { Satisfaction with } \\
\text { Factory Environment } \\
\text { (Score) }\end{array}$ & -0.169 & -3.421 & 0.001 \\
\hline
\end{tabular}

http://www.shanlaxjournals.com

\begin{tabular}{|l|c|c|c|}
\hline $\begin{array}{l}\text { Social Status } \\
\text { Background } \\
\text { (3 Categories) }\end{array}$ & -0.127 & 2.622 & 0.01 \\
\hline $\begin{array}{l}\text { Gender (Ref. Males) } \\
\text { Females }\end{array}$ & -0.107 & -2.218 & 0.05 \\
\hline $\begin{array}{l}\text { Nativity (Ref. Rural) } \\
\text { Urban }\end{array}$ & -0.172 & -3.512 & 0.001 \\
\hline $\begin{array}{l}\text { Assets Owned } \\
\text { (Ref. No) } \\
\text { Yes }\end{array}$ & 0.097 & 1.977 & 0.05 \\
\hline $\begin{array}{l}\text { Debt (Ref. No) } \\
\text { Yes }\end{array}$ & 0.111 & 2.248 & 0.05 \\
\hline $\begin{array}{l}\text { F-Value; Sig. Level } \\
\quad \text { R } \text { (in \%) } \\
\text { Total Sample }\end{array}$ & \multicolumn{3}{|c|}{$25.11 .338 ; \mathrm{p}<0.001$} \\
\hline
\end{tabular}

Here, an attempt is made to find out the major determinants of the number of occupational health problems from which the respondents suffered / experienced, making use of multiple linear regression analysis. Such multivariate analysis allows us an accurate assessment of each of the explanatory variables (background characteristics) by taking into account the potential confounding effects of other variables used in the model. For this purpose, the number of occupational-related health problems considered here as a dependent variable, which is measured as discrete (i.e., the actual number of occupational health problems experienced by the respondents). The independent (explanatory) variables considered here for analysis are based on the theoretical importance and their levels of significance with the dependent variable. Of the ten variables included in the model, six are treated as discrete, and the other 4 are dummy variable type ( 2 categories only - for details see Table above).

Results based on multiple linear regression analysis (Table 1 ) highlights that all the ten variables included in the model together have explained 25.1 percent of the variation in the number of work-related health problems suffered by the respondents during the 12 monthly preceding the survey $(\mathrm{F}=11.338$; $\mathrm{p}<0.001)$. Controlling for all the variables included in the model, the likelihood of suffering from occupational-related health problems by the respondents appeared to be increasing in a highly significant way with their current age $(\beta=0.192$; $\mathrm{p}<0.001)$. It is conspicuous to note that respondents 
who have dept have shown a fairly higher propensity to suffer from more number of work-related health problems than those who do not have any debt, and statistically, this finding has turned out as moderately significant $(\beta=0.111 ; \mathrm{p}<0.05)$.

Conversely, the probability of suffering from one or more work-related health problems is likely to decrease significantly with an increase in the respondents' satisfaction level with the factory environment $(\beta=-0.169 ; p<0.001)$ and in an increase in their level of education $(\beta=-0.154$; $\mathrm{p}<0.01$ ). Another eye-catching finding is that respondents whose nativity is urban areas have exhibited significantly lower odds of suffered from occupational health problems. Next to these, it is also striking to note that social status background (caste as social strata) has demonstrated a net effect, in a negative direction, on their extent of suffering from work-related health problems $(\beta=-0.127 ; \mathrm{p}<0.01)$. This finding supports the fact that members belong to higher caste groups (BCs in the present context) are likely to suffer from lesser number of health problems closely followed by MBCs, whereas respondents who belonged to SC / ST (lower in social strata) have reported being suffering from a higher number of such health problems. Another worth finding noted here is that as respondents type of labor increase from unskilled to semi-skilled and then to skilled, there seems to be a decrease in the number of health problems they suffered, and statistically, such association is moderately significant $(\beta=-0.114$; $p<0.05)$. Yet another conspicuous finding it that female respondents have shown a lower tendency to suffer from occupation-related health problems than their male counterparts at a moderately significant extent $(\beta=-0.107 ; p<0.01)$. All these findings are on the expected lines.

Contrary to the expectation, respondents who own assets have reported being suffered from a higher number of occupational-related health problems than those who do not own such assets $(\beta=0.154 ; \mathrm{p}<0.01)$. It is considerable to note that though the likelihood of suffering from occupational health problems by the respondents appears to be decreasing with their average earnings per month, the t-test statistics didn't turn out as significant $(\beta=-0.154 ; p<0.01)$

\section{Conclusion}

In sum, from the results above, it is conspicuous to note that the sample industrial workers appear to be suffering from occupational-related health problems has increased with an increase in their current age, and such likelihood is also noted as moderately higher among those who are in debt; but unexpectedly such suffering from health problems is also found to be higher among those who own assets. On the other hand, the tendency to suffered from different work-related health problems has decreased with an increase in the respondents' satisfaction with factory environment, level of education, social status (caste background, SC/ST, MBC, and $\mathrm{BC}$ ), and type of labor (unskilled, semi-skilled and skilled). Likewise, the odds of suffering from one or more occupational-related health problems seem to be lower among those whose nativity is urban areas, and gender is female.

\section{References}

Aidoo, Abdul Wahab. "The Influence of Stress on the Health of Workers in Manufacturing Industry." Sarajevo Journal of Social Science Inquiry, vol. 2, no. 2, 2016, pp. 65-75.

Bartkiewicz, Piotr, et al. Evaluation of Benefits to the EU-15 Countries Resulting from the Implementation of the Cohesion Policy in the Visegrad Group Countries, IBS Research Reports 02/2011.

Baskar, R., and V.Anupiriya. "A Study on Health Hazards of Coimbatore Corporation Sanitary Workers, Tamilnadu, India." Review of Research, vol. 8, no. 3, 2018.

Dembe, Allard E. "The Social Consequences of Occupational Injuries and Illnesses." American Journal of Industrial Medicine, vol. 40, no. 4, 2001, pp. 403-417.

Houtman, Irene, and Karin Jettinghoff. "Raising Awareness of Stress at Work in Developing Countries." Protecting Workers' Health series No. 6, 2007.

Khan, N.R. "Occupational Health Hazards among Workers of Garment Factories in Dhaka City, Bangladesh." Journal of Dhaka Medical College, vol. 24, no. 1, 2015, pp. 36-43. 
Kramer, M., etal. "The ICD-9 Classification of Mental Disorders: A Review of Its Developments and Contents." Acta Psychiatrica Scandinavica, vol. 59, no. 3, 1979, pp. 241-262.

Michie, S. "Causes and Management of Stress at Work." Occupational Environmental Medicine, vol. 59, no. 1, 2002, pp. 67-72.

Padmini, D.S., and A. Venmathi. "Unsafe Work Environment in Garment Industries, Tirupur, India." Journal of Environmental Research and Development, vol. 7, no. 1, 2012, pp. 569-575.
Ravichandran, Sreesupria P., and Pankaj B. Shah. "Health Problems and Risk Factors Prevailing among Garment Workers in Tirupur, Tamil Nadu." International Journal of Community Medicine and Public Health, vol. 5, no. 6, 2018, pp. 2400-2405.

Satheesh Kumar, K. An Analysis of Work Related Stress Factor in Selected Industries in Kerala, India, Cochin University of Science and Technology, 2011.

Silver, Caleb. "The Top 20 Economies in the World." Investopedia, 2020.

\section{Author Details}

Dr. A. Sangamithra, Professor, Department of Economics, Bharathiar University, Coimbatore, Tamil Nadu, India, Email ID: sangamithra@buc.edu.in.

P. Sindia, Research Scholar, Department of Economics, Bharathiar University, Coimbatore, Tamil Nadu, India,

Email ID: sindiabenny@gmail.com. 